Doi: $10.4274 /$ vhd. 46220

Viral Hepatitis Journal 2014; 20(2): 61-63

\title{
Impact of Storage Time of Fresh Serum Samples on Rapid Test Results of HBsAg
}

\author{
Taze Serum Örneklerinde Bekleme Süresinin HBsAg Hızlı Test Sonuçlarına Etkisi
}

\author{
Zafer MENGELOĞLU, Özlem BUCAK, Esra KOÇOĞLU, Tekin TAŞ, Şeyda KARABÖRK
}

Abant Izzet Baysal University Faculty of Medicine, Department of Medical Microbiology, Bolu, Turkey

\begin{abstract}
Objective: Rapid tests, amongst the methods used in the diagnosis of hepatitis B virus infection, detect hepatitis $B$ surface antigen (HBsAg). It is important to know whether the elapsed time between sample collection and the process has negative impact on the test results. It was aimed to evaluate the impact of samples stored either at room temperature (RT) or at $+4{ }^{\circ} \mathrm{C}$ for different durations on rapid test results.

Materials and Methods: A total of 51 serum samples were used. HBsAg tests were performed at the time the samples arrived at our laboratory using chemiluminescence method. 21 samples positive for HBsAg were accepted as the study group, and 30 negative samples were the controls. All the samples were tested immediately using rapid assay. Then the samples were divided into two aliquots and divided again into two groups; the first group was stored at $\mathrm{RT}$, and the second was stored at $+4^{\circ} \mathrm{C}$. Two or three hours after the first tests, all the samples were tested again using rapid assay, and then, they were continued to be stored; and after 24 hours, the tests were repeated for the third time. Test results were scored between "negative" and " +++ ". Results: In the initial rapid tests, the sensitivity rate was $85.7 \%$, and the specificity was $100 \%$. A statistically significant association was found between the positivity grades and the mean HBsAg levels $(p<0.001 ; r=0.831)$. The accuracy was found to be $96.1 \%(49 / 51)$ for the second hour tests in terms of positivity grades. It was observed that the accuracy rate was decreased to $84.3 \%(43 / 51)$ in samples stored for 24 hours in both conditions, and positivity grades of eight samples were decreased for one degree for each. Amongst all tests, no false negative and false positive results were obtained according to the initial tests. In addition, it was found that all the results of the samples stored either at $\mathrm{RT}$ or $+4^{\circ} \mathrm{C}$ overlapped, and that the difference was caused just by the duration of storage.

Conclusion: In conclusion, sera should not be stored for long time in cases they will be tested using HBsAg rapid assays, and storage of the samples for one day decrease the reliability of the results. (Viral Hepatitis Journal 2014; 20(2): 61-63)

Key words: Rapid test, HBsAg, storage time, storage conditions, HBV
\end{abstract}

\section{ÖZET}

Amaç: Hepatit B enfeksiyonun tanısında kullanılan yöntemlerden olan hızlı testler hepatit B yüzey antijenini (HBsAg) saptamaktadır. Bu testlerde, örneklerde işlem öncesi geçen sürenin sonuca olumsuz etki edip etmediğinin bilinmesi önemlidir. Bu çalışmada, oda ısısında veya $+4^{\circ} \mathrm{C}$ 'de farklı sürelerde bekletilmiş serum örneklerinin HBsAg hızlı test sonuçlarına etkisinin incelenmesi amaçlandı.

Gereç ve Yöntemler: Çalışma için toplam 51 serum örneği kullanıldı. Örnekler laboratuvarımıza ilk geldiğinde kemilüminesans metodu ile HBsAg testleri çalışıdı. Bu testler sonucunda negatif olan 30 örnek kontrol grubu olarak, pozitif sonuçlanan 21 örnek ise çalışma grubu olarak ayrıldı. Tüm örnekler bekletilmeden hızı HBsAg testi çalışıldı. Daha sonra örneklerin her biri ikiye bölünüp alikotlandı ve yine ikişer gruba ayrıldl; birinci grup oda ısısında, ikinci grup ise buzdolabında $+4{ }^{\circ} \mathrm{C}$ 'de bekletildi. Ilkk testlerden 2-3 saatlik bir zaman geçtikten sonra bekletilen tüm örnekler için hızlı testler yeniden uygulandı ve ardından aynı koşullarda bekletilmeye devam edildi. Illk testlerden toplam 24 saat geçtikten sonra tüm örnekler için hızlı testler 3. kez çalışıldı. Test sonuçları "negatif" ile "+++" arasında skorlanarak sonuçlandıııdı. Bulgular: IIk yapılan hızlı testlerde duyarlıık oranı \%85,7; özgüllük oranı \%100 olarak bulundu. Bu testlerde örneklerin pozitiflik dereceleri ile ortalama $\mathrm{HBsAg}$ değerleri istatistiksel olarak ilişkili bulundu $(p<0,001 ; r=0,831)$. Pozitiflik dereceleri bakımından, ikinci saat testleri için uyumluluk \%96,1 (49/51) olarak hesaplandı. Farklı iki ısı ortamında 24 saat bekleyen örneklerde ise uyumluluk oranının \%84,3'e (43/51) gerilediği görüldü, toplam sekiz örneğin pozitiflik derecesinin bir derece indiği gözlendi. Tüm testlerde ilk hızlı test sonuçlarına göre hiçbir yalancı pozitifliğe ve yalancı negatifliğe rastlanmadı. Ayrıca oda ısısı ve $+4^{\circ} \mathrm{C}$ 'de bekletilen örneklerin test sonuçlarının birbirleriyle tam olarak örtüştüğü; farklıı̆̆ın sadece bekletilen süreden kaynaklandığı sonucu ortaya çıktı.

Sonuç: Sonuç olarak, çalışamızda ulaşılan bu veriler, hızı HBSAg testi yapılacak olan durumlarda örneklerin birkaç saatten fazla bekletilmemesi gerektiğini, bir günlük bekletmenin sonucun güvenilirliğini azalttığını gösterdi. (Viral Hepatit Dergisi 2014; 20(2): 61-63)

Anahtar Kelimeler: Hızlı test, HBsAg, bekleme süresi, bekleme koşulları, HBV 


\section{Introduction}

Hepatitis B is an important infection that is common throughout the world and that can manifest in a wide range from asymptomatic disease to fatal conditions. Laboratory diagnosis of this disease is crucial. Screening tests are recommended for hepatitis B virus (HBV) infection, particularly for risky groups. Serological tests detecting hepatitis B surface antigen ( $\mathrm{HBsAg}$ ) are the methods of first choice for the diagnosis of this infection $(1,2)$.

Rapid assays, known as card tests or cassette tests, can be preferred for being easy-to-perform and low cost procedures, however, they are not widely used in laboratories because of their lower sensitivity compared to the other developed systems. Besides this, they have been used in small-sized laboratories and in blood transfusion units in some emergency cases (1-3).

It is critical to know whether transport conditions of the blood, serum and plasma samples or the elapsed time passed between sample collection and the process have negative impacts on the test results in the diagnosis of HBV infection. In addition, in which conditions the samples can be stored for a short period in cases of the transfer or the process cannot be performed immediately, is the question to be answered.

In the present study, it was aimed to evaluate the effects of storage conditions of serum samples at room temperature (RT) or $+4{ }^{\circ} \mathrm{C}$ for various periods on rapid tests of $\mathrm{HBsAg}$.

\section{Materials and Methods}

\section{Serum Samples and the Tests}

A total of 51 serum samples were used for the study. Sera were tested using chemiluminescence technology system (Architect i2000sr, IL, USA) at the time they arrived at the microbiology laboratory in our hospital. A total of 30 samples that were found to be negative for HBsAg with these tests were used as the control group, and 21 sera that were positive were accepted as the study group. HBsAg rapid tests were performed for all the

\begin{tabular}{|l|l|l|}
\hline \multicolumn{3}{|l|}{$\begin{array}{l}\text { Table 1. The mean HBsAg levels of the samples according to the } \\
\text { positivity grades obtained from the initial rapid tests }\end{array}$} \\
\hline Test result & $\mathbf{n}$ & HBsAg Mean \pm SD $^{*}$ \\
\hline Negative & 33 & $60.44 \pm 294.79$ \\
\hline$(+)$ & 5 & $2724.00 \pm 2103.98$ \\
\hline$(++)$ & 7 & $3587.14 \pm 1399.40$ \\
\hline$(+++)$ & 6 & $5031.33 \pm 1069.99$ \\
\hline Total & 51 & $1390.44 \pm 2090.66$ \\
\hline
\end{tabular}

*Standard deviation samples following chemiluminescence tests. Then, the samples were aliquoted into two and divided into two groups, the first group was stored at RT and the second was stored in the refrigerator at $+4{ }^{\circ} \mathrm{C} \mathrm{C}$. After 2 or 3 hours, all the aliquots were tested again using the rapid tests, and immediately put in the same storage conditions again. Twenty-four hours after the initial tests, all the aliquots were tested for the third time.

Nanosign HBsAg rapid test kit (Bioland, South Korea) was used for the study according to the recommendations of the manufacturer. The test results were scored between "negative" and " $(+++)$ ". The test results of the chemiluminescence were accepted as the quality control standard.

\section{Statistical Analysis}

For the statistical analysis, SPSS 15.0 software (IBM SPSS Inc., Chicago, IL, USA) was used. The Shapiro-Wilk test was used to evaluate whether the continuous variables were normally distributed. Spearman's correlation was used for the analysis of associations between variables. The values were expressed as the mean \pm standard deviation. The Kruskal-Wallis test was used for the comparison of the means between the groups. A p value of less than 0.05 was considered statistically significant.

\section{Results}

All the negative samples and three of 21 positive samples detected by the chemiluminescence system to be negative in the initial rapid tests. According to this finding, the sensitivity and the specificity of the rapid test were found to be 85.7 and $100 \%$, respectively. A positive correlation was found between the HBsAg levels and the positivity grades of the samples $(p=0.001 ; r=0.831)$ (Table 1).

Positivity grades of only two sera decreased from $(+++)$ to $(++)$ in the tests performed 2 or 3 hours after the initial tests among all samples either stored at $\mathrm{RT}$ or $+4{ }^{\circ} \mathrm{C}$, and in these tests, all the remaining samples revealed the same positivity grade with the first results meaning the concordance of $96.1 \%$ (49/51). In the samples stored for 24 hours in both conditions, the concordance rate was decreased to $84.3 \%(43 / 51)$, and positivity grades also decreased one degree in eight samples. No tests revealed any false positive or false negative results (Table 2 ). In addition, the results of the samples stored either at RT or $+4{ }^{\circ} \mathrm{C}$ fully overlapped, thus, it was found that the difference in the results were only due to the durations of the storage.

No significant difference was found between HBsAg levels of the samples of that the positivity grades were decreased after 24 hours of storage and the samples that showed the same positivity grades with the initial tests $(p=0.204)$ (Table 3$)$.

\begin{tabular}{|c|c|c|c|c|c|c|c|c|c|c|}
\hline \multirow{2}{*}{\multicolumn{2}{|c|}{ Results }} & \multicolumn{4}{|c|}{ After 2-3 hours (At RT* or at $+4^{\circ} \mathrm{C}$ ) } & \multicolumn{5}{|c|}{ After 24 hours (At RT or at $+4^{\circ} \mathrm{C}$ ) } \\
\hline & & $\begin{array}{l}(-) \\
33 \\
- \\
- \\
-\end{array}$ & $\begin{array}{l}(+) \\
- \\
5\end{array}$ & $\begin{array}{l}(++) \\
- \\
- \\
7 \\
2\end{array}$ & $\begin{array}{l}(+++) \\
- \\
- \\
- \\
4\end{array}$ & $\begin{array}{l}(-) \\
33 \\
- \\
- \\
-\end{array}$ & $\begin{array}{l}\text { Weak positive } \\
- \\
3 \\
- \\
-\end{array}$ & $\begin{array}{l}(+) \\
- \\
2 \\
1 \\
-\end{array}$ & $\begin{array}{l}(++) \\
- \\
- \\
6 \\
4\end{array}$ & $\begin{array}{l}(+++) \\
- \\
- \\
- \\
2\end{array}$ \\
\hline
\end{tabular}

${ }^{*} \mathrm{RT}$ : Room temperature 


\begin{tabular}{|l|l|l|}
\hline Table 3. The mean HBsAg levels of the samples that positivity grades were decreased or that remained the same according to the initial rapid tests \\
\hline Test results & $\mathbf{n}$ & HBsAg Mean \pm SD* \\
\hline Positivity grades remained the same & 13 & $2940.54 \pm 1984.38$ \\
\hline Positivity grades decreased & 8 & $4084.75 \pm 1851.64$ \\
\hline
\end{tabular}

${ }^{*}$ Standard deviation

\section{Discussion}

HBsAg screening assays, commonly used as first step tests in laboratory diagnosis of HBV infection, can be helpful in early management of the disease. Rapid diagnosis of this infection may be crucial in some cases. However, the importance of sensitivity, specificity and accuracy of the rapid tests is controversial. Transport conditions and the durations before the process of the samples that will be tested also cannot be standardized in several laboratories, and therefore, it is important to know whether these situations have negative impact on the test results $(1,4,5)$.

The sensitivity rates of the HBsAg rapid tests have been reported to be between $65 \%$ and $95 \%(6,7)$. The sensitivity was found as not very high as approximately $85 \%$ in our study, however, the specificity was $100 \%$ compared to the results of the chemiluminescence method. According to this finding, it is observed that the rapid test could not detect all the sera with HBsAg, however, it could be very helpful if it revealed positive. Besides this, it is well known that HBsAg negative results obtained using even the most reliable methods cannot rule out the presence of the infection due to lack of HBsAg detection either in the initial periods or in the window period of the disease $(4,6)$.

In the present study, a significant correlation was found between HBsAg levels in the sera and the positivity grades detected by rapid test, according to this finding, a high grade positive result can predict high level of HBsAg.

Storage conditions of sera samples have been reported to affect the performance of rapid tests in the diagnosis of $\mathrm{HBV}, \mathrm{HCV}$ and HIV infections $(5,8)$. In the present study, storage of the sera for a two or three hours either at RT or at $+4{ }^{\circ} \mathrm{C}$ was found to decrease the positivity grades slightly, however, it did not cause any false positive and false negative results. However, positivity grades were shown to decrease in a high rate when the sera were stored for 24 hours in both conditions, but this storage duration of one day even did not cause false negative or false positive results. In addition to this, both storage conditions did not cause results different from each other, and the decrease in the positivity levels was found to be caused only by the durations.

In conclusion, data obtained from the present study suggested that serum samples that would be tested for HBsAg using rapid tests were not supposed to be stored more than a few hours, and that a one day delay decreased the reliability of the results.
In addition, it was concluded that storage of the samples in the refrigerator could not prevent the decrease in the sensitivity and could not provide the storage duration to be extended. When the findings about the lack of negative impact of one freeze-thaw cycle on the results of rapid tests obtained from our another study (Unpublished data) combined with the findings of the present study, it can be concluded that freezing of serum samples that are to be halted can cause less negative effects on the test results.

\section{Acknowledgement}

This study was supported by Viral Hepatitis Prevention Society.

\section{Conflict of interest: None declared.}

\section{References}

1. Weinbaum CM, Williams I, Mast EE, Wang SA, Finelli $L$, Wasley $A$, et al. Recommendations for identification and public health management of persons with chronic hepatitis $B$ virus infection. MMWR Recomm Rep. 2008; 57(RR-8): 1-20.

2. Randrianirina F, Carod JF, Ratsima E, Chrétien JB, Richard V, Talarmin A. Evaluation of the performance of four rapid tests for detection of hepatitis B surface antigen in Antananarivo, Madagascar. J Virol Methods. 2008; 151(2): 294-7.

3. Lin $Y H$, Wang $Y$, Loua A, Day GJ, Qiu Y, Nadala EC Jr, et al. Evaluation of a new hepatitis $B$ virus surface antigen rapid test with improved sensitivity. J Clin Microbiol. 2008; 46(10): 331924.

4. Hwang $\mathrm{SH}$, Oh HB, Choi SE, Kim HH, Chang $\mathrm{CL}$, Lee EY, et al. Meta-analysis for the pooled sensitivity and specificity of hepatitis B surface antigen rapid tests. Korean $\mathrm{J}$ Lab Med. 2008; 28(2): 160-8.

5. Bienek DR, Charlton DG. The effect of simulated field storage conditions on the accuracy of rapid user-friendly blood pathogen detection kits. Mil Med. 2012; 177(5): 583-8.

6. Bottero J, Boyd A, Gozlan J, Lemoine M, Carrat F, Collignon A, et al. Performance of rapid tests for detection of HBsAg and anti-HBsAb in a large cohort, France. J Hepatol. 2013; 58(3): 473-8.

7. Cha YJ, Kum DG, Kim SW, Kim TY, Kim JR, Kim HS, et al. Annual report on external quality assessment in immunoserology in Korea (2002). J Lab Med \& Quality Assurance. 2003; 25: 51-72.

8. Lau DT, Ma H, Lemon SM, Doo E, Ghany MG, Miskovsky E, et al. A rapid immunochromatographic assay for hepatitis $B$ virus screening. J Viral Hepat. 2003; 10(4): 331-4. 